\title{
PENGGUNAAN AHP (ANALYTICAL HIERARCHY PROCESS) DALAM EVALUASI PENERAPAN PEMBIAYAAN BERDASARKAN ANALISIS PRINSIP PEMBIAYAAN PADA PT. BPRS AMANAH UMMAH
}

\author{
Irfan Ibnu Faaiz \\ STAI al-Munahayah Garut \\ Email: ibnu_faaiz@gmail.com
}

\begin{abstract}
Abstrak: Di Indonesia, terdapat dua jenis lembaga perbankan yaitu perbankan konvensional dan perbankan syariah. Dalam Undang-undang no. 21 Tahun 2008 tentang perbankan syariah dikatakan "bahwa perbankan syariah memiliki kekhususan dibandingkan dengan perbankan konvensional". Yaitu dalam pelaksanaan operasionalnya bank syariah menggunakan prinsip-prinsip syariah Islam, dan tidak menjalankan sistem bunga.
\end{abstract}

Kata Kunci: Pembiayaan, BPR, Perbankan

\section{Pendahuluan}

Semakin berkembangnya perekonomian suatu negara, maka semakin meningkat pula kebutuhan pendanaan untuk membiayai proyek-proyek pembangunan. Namun, dana pemerintah yang bersumber dari APBN dan pihak swasta sangat terbatas untuk menutup kebutuhan dana tersebut. Dengan keterbatasan kemampuan financial lembaga dan swasta tersebut, maka perbankan nasional memegang peranan penting dan strategis dalam kaitannya penyediaan permodalan pengembangan sektor-sektor produktif. ${ }^{2}$ Melihat keadaan tersebut, peranan perbankan dalam mencapai tujuan

${ }^{1}$ Undang-undang Republik Indonesia Nomor. 21 Tahun 2008 Tentang Perbankan Syariah.

${ }^{2}$ Muhammad, Manajemen Pembiayaan Bank Syariah (Yogyakarta: Unit Penerbit Dan Percetakan Akademi Manajemen Perusahaan YKPN, 2005), h.15. 
pembangunan nasional sangat strategis yaitu dengan memenuhi kebutuhan pihak defisit unit dalam rangka mengembangkan dan memperluas usaha.

Di Indonesia, terdapat dua jenis lembaga perbankan yaitu perbankan konvensional dan perbankan syariah. Dalam Undang-undang no. 21 Tahun 2008 tentang perbankan syariah dikatakan "bahwa perbankan syariah memiliki kekhususan dibandingkan dengan perbankan konvensional"3. Yaitu dalam pelaksanaan operasionalnya bank syariah menggunakan prinsip-prinsip syariah Islam, dan tidak menjalankan sistem bunga.

Secara kelembagaan, perkembangan perbankan syariah di Indonesia ditandai dengan ditandatanganinya akte pendirian Bank Muamalat Indonesia (BMI) pada tanggal 1 November $1991,{ }^{4}$ dan baru mulai beroperasi pada 1 Mei 1992. Kemudian baru menyusul bank-bank lain yang membuka jendela syariah (Islamic Window) dalam menjalankan kegiatan usahanya dengan terlebih dahulu membentuk UUS (Unit Usaha Syariah). Sedangkan secara yuridis dimulai dengan diundangkannya UU Nomor 7 tahun 1992 yang memuat ketentuan-ketentuan yang secara implisit memperbolehkan pengelolaan bank dengan pronsip bagi hasil (profit and loss sharing ). Kemudian dipertegas lagi dengan membedakan bank berdasarkan pada pengelolaannya yang terdiri dari bank konvensional dan bank syariah melalui UU Nomor 10 tahun 1998 yang merupakan amandemen dari UU sebelumnya. ${ }^{5}$ Dan dengan diberlakukannya UU Nomor 21 tahun 2008 tentang perbankan syariah yang terbit pada tanggal 16 Juli 2008, maka pengembangan industri perbankan syariah nasional semakin memiliki landasan hukum yang memadai dan akan mendorong pertumbuhannya secara lebih cepat lagi. ${ }^{6}$

Perjalanan perbankan syariah di Indonesia hingga saat ini telah mengalami kemajuan yang pesat, hal ini ditunjukkan dengan selalu ber-

${ }^{3}$ Undang-undang Republik Indonesia Nomor. 21 Tahun 2008 Tentang Perbankan Syariah

${ }^{4}$ Muhammad Syafi'i Antonio, Bank Syariah: Dari Teori ke Praktik (Jakarta: Gema Insani Press, 2001), h. 25.

${ }^{5}$ Abdul Ghafur Anshori, Perbankan Syariah Di Indonesia (Yogyakarta: Gadjah Mada University Press, 2007), h.30.

${ }^{6}$ Bank Indonesia, "Sekilas Perbankan Syariah Di Indonesia”, artikel diakses pada 11 Desember 2009 dari http://www.bi.go.id/web/id/Perbankan/Perbankan+Syariah/ 
tambahnya jaringan kantor perbankan syariah di Indonesia dari tahun ke tahun. Dalam statistik perbankan syariah yang dikeluarkan BI, hingga bulan Januari 2010 terdapat 1.346 jaringan kantor perbankan syariah.

Tabel 1.1

Jaringan Kantor Perbankan Syariah (Islamic Banking Network)

(2006 - Januari 2010)

\begin{tabular}{|lccccc|}
\hline & 2006 & 2007 & 2008 & 2009 & $\begin{array}{c}\text { Jan- } \\
2010\end{array}$ \\
\hline Bank Umum Syariah (BUS) & & & & & \\
\hline Jumlah Bank & 3 & 3 & 5 & 6 & 6 \\
\hline Jumlah Kantor & 349 & 401 & 581 & 711 & 815 \\
\hline Unit Usaha Syariah & & & & & \\
\hline $\begin{array}{l}\text { Jumlah Bank Umum Konvensional } \\
\text { yang Memiliki UUS }\end{array}$ & 20 & 26 & 27 & 25 & 25 \\
\hline Jumlah Kantor & 183 & 196 & 241 & 287 & 268 \\
\hline Bank Pembiayaan Rakyat Syariah (BPRS) & & & & & \\
\hline Jumlah Bank & 105 & 114 & 131 & 138 & 140 \\
\hline Jumlah Kantor & 105 & 185 & 202 & 225 & 263 \\
\hline JUMLAH KANTOR & 637 & 782 & 1024 & 1223 & 1346 \\
\hline
\end{tabular}

Sumber: Statistik Perbankan Syariah Januari 2010 (www.bi.go.id)

Menurut peneliti Rodney Wilson terdapat banyak potensi pasar yang perlu digali, hal tersebut menunjukkan masih luasnya potensi yang tersedia bagi bank syariah. ${ }^{7}$ Penggalian potensi tersebut dapat dilakukan dengan pengalokasian penyaluran pembiayaan yang tepat.

Seperti layaknya bank konvensional, bank syariah merupakan lembaga keuangan (financial intermediary) yang tugas pokoknya adalah meng-

${ }^{7}$ Dhani Gunawan, "Perbankan Syariah Menuju Millenium Baru: Suatu Tinjauan Pengembangan, Pengawasan dan Prospek", artikel diakses pada tanggal 7 Desember 2009 dari http://www.bi.go.id/NR/rdonlyres/E736319E-6D52-4199-ACF9-247D719BF119/3018/ bempvol2no3des99.pdf 
himpun dana dari masyarakat dan dari dana tersebut dapat memenuhi kebutuhan dana dalam bentuk pembiayaan. ${ }^{8}$

Prinsip pembiayaan pada bank syariah harus sesuai dengan prinsip syariah, yaitu aturan perjanjian berdasarkan hukum Islam. Antara lain, pembiayaan berdasarkan prinsip bagi hasil (mudharabah), pembiayaan berdasarkan penyertaan modal (musyarakah), prinsip jual beli barang dengan prinsip jual beli barang dengan memperoleh keuntungan (murabahah), pembiayaan barang modal berdasarkan prinsip sewa murni tanpa pilihan (ijarah), pembiayaan barang modal berdasarkan prinsip dengan adanya pilihan pemindahan atas barang yang disewa dari pihak bank oleh pihak lain (ijarah wal iqtina). ${ }^{9}$

Menjalankan kegiataan pembiayaannya, bank syariah memiliki pedoman berupa prinsip analisis pembiayaan, yaitu pedoman-pedoman yang harus diperhatikan oleh pejabat pembiayaan bank syariah pada saat melakukan analisis pembiayaan. ${ }^{10}$

Salah satunya adalah BPRS Amanah Ummah, dalam laporan keuangan tahun 2008 penyebaran pembiayaan menurut porsinya terhadap sektor ekonomi adalah sebagai berikut; sektor perdagangan (55.92\%), disusul pembiayaan konsumtif $(30.18 \%)$, jasa (5\%), pertanian $(2.39 \%)$, terakhir sektor industri (1.96\%). ${ }^{11}$

Tabel 1.2

Pembiayaan Per-Sektor PT. BPRS Amanah Ummah

Tahun 2007 - 2008

(Dalam Ribuan)

\begin{tabular}{lllll}
\hline \multirow{2}{*}{ SEKTOR } & 2007 & \multicolumn{3}{l}{2008} \\
\cline { 2 - 5 } & NOMINAL & $\%$ & NOMINAL & $\%$ \\
\hline Perdagangan & $12,275,309$ & 36.02 & $19,053,922$ & 55.92 \\
\hline
\end{tabular}

${ }^{8}$ Muhammad, Manajemen Pembiayaan Bank Syariah, h.15.

${ }^{9}$ Rachmadi Usman, Aspek-Aspek Hukum Perbankan Di Indonesia (Jakarta: PT. Gramedia Pustaka Utama, 2001), h. 40-41.

${ }^{10}$ Muhammad, Manajemen Pembiayaan Bank Syariah, h.60.

${ }^{11}$ PT. BPRS Amanah Ummah, Laporan Tahunan 2008 (Bogor: PT. BPRS Amanah Ummah, 2008), h. 21. 


\begin{tabular}{lllll}
\hline Konsumtif & $7,371,908$ & 30.08 & $10,282,778$ & 30.18 \\
\hline Jasa & $3,454,213$ & 10.14 & $3,254,441$ & 5 \\
\hline Pertanian & 610,389 & 2.49 & 814,799 & 2.39 \\
\hline Industri & 796,793 & 2.34 & 669,022 & 1.96 \\
\hline
\end{tabular}

Sebagai salah satu lembaga kepercayaan masyarakat BPRS Amanah Ummah harus mampu memenuhi kebutuhan masyarakat dalam sisi permodalan. Namun, sebagai sektor keuangan yang bergerak dibidang moneter juga harus memperhatikan sisi likuiditas agar resiko yang akan dihadapi dapat diminimalisir dan pada akhirnya akan menciptakan pembiayaan yang produktif bagi bank.

\section{Produk Pembiayaan Bank Syariah}

Menurut Muhammad, pembiayaan atau financing adalah pendanaan yang diberikan oleh suatu pihak kepada pihak lain untuk mendukung investasi yang telah direncanakan, baik dilakukan sendiri ataupun lembaga. Dengan kata lain, pembiayaan adalah pendanaan yang dikeluarkan untuk mendukung investasi yang telah direncanakan. ${ }^{12}$

Dalam kaitannya dengan perbankan syariah, jenis pembiayaan menurut sifat penggunaannya, pembiayaan dapat dibagi dalam: ${ }^{13}$ (1) Pembiayaan konsumtif. Bank syariah dapat menyediakan pembiayaan konsumtif dengan menggunakan skema jual beli dengan angsuran (ba'i bitsaman ajil), atau sewa beli (ijarah muntahia bi tamlik), atau melalui kemitraan dengan pertisipasi menurun (musyarakah mutanaqisah). ${ }^{14}$ (2) Pembiayaan produktif. ${ }^{15}$ (3) Pembiayaan modal kerja peningkatan produksi, bank syariah menggunakan skema pembiayaan mudharabah (trust financing). (4) Pembiayaan modal kerja untuk perdagangan, bank syariah menggunakan skema pembiayaan mudharabah untuk perdagangan masal, dan skema pembiayaan murabahah dan musyarakah untuk perdagangan berdasarkan pesanan (impor). (5) Pembiayaan

\footnotetext{
${ }^{12}$ Muhammad, Manajemen Pembiayaan Bank Syariah, h.17.

${ }^{13}$ Zainul Arifin, Dasar-Dasar Manajemen Bank Syariah, cet.IV, h. 200-208.

${ }^{14}$ Zainul Arifin, Dasar-Dasar Manajemen Bank Syariah, cet.IV, h. 201.

${ }^{15}$ Zainul Arifin, Dasar-Dasar Manajemen Bank Syariah, cet.IV, h. 201-206.
} 
likuiditas, bank syariah mengguakan giro wadiah. (6) Pembiayaan piutang, bank syariah menggunakan skim bentuk qard dan wakalah. (7) Pembiayaan persediaan, bank syariah menggunakan prinsip jual beli (ba'i) yaitu murabahah, istishna, ba'i salam.

\section{Analisis Kelayakan Pembiayaan}

Menurut Muhammad, analisis pembiayaan dimaksudkan untuk: (1) menilai kelayakan usaha calon peminjam; (2) menekan resiko akibat tidak terbayarnya pembiayaan; (3) menghitung kebutuhan pembiayaan yang layak. ${ }^{16}$ Setelah tujuan analisis pembiayaan dirumuskan dan disepakati, selanjutnya dapat ditemukan pendekatan-pendekatan yang akan digunakan dalam analisis pembiayaan.

Aslam hasan mengatakan, didalam buku mengenai Credit Management Handbook karya Prof. Dr.H. Veithzal Rivai M.B.A dan Andria Permata Veithzal, B.Acct., M.B.A secara lengkap beberapa pendekatan yang dapat digunakan, yakni Character Approach, Collateral Approach, Repayment Approach, Feasibility Approach, Agent Of Development Approach dan Relationship Approach. ${ }^{17}$ Hal tersebut dilakukan atas dasar pembiayaan yang diberikan mengandung resiko.

Dalam hal prinsip analisis pembiayaan, bank biasanya menerapkan prisip $5 \mathrm{C}$ atau disebut dengan the five $C$ of credit analysis, dan ditambah dengan $1 \mathrm{C}$ yaitu: ${ }^{18}$

1. Character, yaitu sifat atau karakter nasabah pengambil pinjaman.

2. Capacity, artinya kemampuan nasabah untuk menjalankan usaha dan mengembalikan pinjaman yang diambil.

3. Capital, artinya besarnya modal yang diperlukan peminjam.

4. Collateral, artinya jaminan yang telah dimiliki yang diberikan peminjam kepada bank.

${ }^{16}$ Muhammad, Manajemen Pembiayaan Bank Syariah, h.59.

${ }^{17}$ Aslam Hasan, "Pendekatan-Pendekatan Dalam Analisis Kredit", artikel diakses pada 5 Januari 2010 dari http://belajarkredit.blogspot.com/2009/11/pendekatan-pendekatandalam-analisis.html

${ }^{18}$ Muhammad, Manajemen Pembiayaan Bank Syariah, h.60. 
5. Condition, artinya keadaan usaha atau nasabah prospek atau tidak.

6. Constraint, artinya hambatan-hambatan yang mungkin mengganggu proses usaha.

Disamping menggunakan prinsip pemberian kredit diatas, bank dalam memberikan kredit juga menggunakan 3R, yaitu: ${ }^{19}$

1. Return, yang menunjukkan hasil yang diharapkan dapat diperoleh dengan penggunaan kredit tersebut.

2. Repayment Capacity, yaitu kemampuan perusahaan pemohon kredit untuk dapat membayar kembali pinjaman pada sat dimana kredit tersebut harus diangsur/dilunasi.

3. Risk Bearing Capacity, yaitu kemampuan untuk menanggung resiko kegagalan atau ketidakpastian yang bersangkutan dengan penggunaan kredit tersebut.

Namun, selain menerapkan prinsip analisis-analisis tersebut, demi mendapatkan informasi mengenai itikad baik (willingness to pay) dan kemampuan membayar (ability to pay) bank juga menerapkan prinsip 5P, yaitu:

1. Party (Para Pihak)

Para pihak merupakan titik sentral yang diperhatikan dalam setiap pemberian kredit. Oleh karena itu, pihak pemberi kredit harus memperoleh suatu "kepercayaan" terhadap para pihak, dalam hal ini debitor. Bagaimana karakternya, kemampuannya, dan sebagainya. ${ }^{20}$

2. Purpose (Tujuan)

Tujuan pemberian kredit juga sangat penting diketahui oleh pihak kreditor. Harus dilihat apakah kredit akan digunakan untuk hal-halyang positif yang benar-benar dapat menaikkan income perusahaan. Dan harus pula diawasi agar kredit tersebut benar-benar diperuntukkan untuk tujuan sepertidiperjanjikan dalam suatu perjanjian kredit. ${ }^{21}$

3. Payment (Pembayaran)

Harus pula diperhatikan apakah sumber pembayaran debitor cukup

${ }^{19}$ Muhammad Firdaus, Manajemen Agribisnis (Jakarta: Bumi Aksara, 2008), h.112

${ }^{20}$ Rachmadi Usman, Aspek-Aspek Hukum Perbankan Di Indonesia, h. 248.

${ }^{21}$ Rachmadi Usman, Aspek-Aspek Hukum Perbankan Di Indonesia, h. 248. 
tersedia dan cukup aman, sehingga dengan demikian diharapkan bahwa kredit yang diluncurkan dapat dibayar kembali oleh debitor yang bersangkutan. ${ }^{22}$

4. Profitability (Perolehan Laba)

Unsur perolehan laba oleh debitor tidak kurang pula pentingnya, untuk itu kreditor harus berantisipasi apakah laba yang akan diperoleh oleh perusahaan dapat menutupi pembayaran kembali. ${ }^{23}$

5. Protection (Perlindungan)

Hal ini diperlukan untuk berjaga-jaga sekiranya terjadi hal-hal di luar skenario atau di luar prediksi semula. ${ }^{24}$

\section{Sektor Pembiayaan}

Dilihat dari sektor yang dibiayai oleh bank syariah, maka pembiayaan bank syariah dapat dialokasikan untuk sektor ekonomi, diantaranya: sektor pertanian, pertambangan, perindustrian, Listrik, air dan gas, konstruksi, perdagangan, pengangkutan, jasa dunia usaha, jasa sosial dan lain-lain. ${ }^{25}$ Namun, pada umumnya, pengalokasian pembiayaan sektor pembiayaan dikelompokkan menjadi:

Pertama, Sektor Pertanian; Kecendrungan akan peningkatan kebutuhan produk-produk bahan pangan menjadikan keberadaan sektor pertanian menjadi semakin penting. Selain itu sebagai penyumbang Produk Domestik Bruto terbesar, sektor ini menjadi sektor yang memiliki pengaruh terhadap setiap perekonomian. ${ }^{26}$ Mengacu kepada sumber daya dan tersedianya potensi lahan yang cukup luas sektor pertanian memiliki prospek yang sangat cerah untuk dimasuki perbankan. ${ }^{27}$

Kedua, Sektor Perindustrian; Pembangunan sektor industri mampu

\footnotetext{
${ }^{22}$ Rachmadi Usman, Aspek-Aspek Hukum Perbankan Di Indonesia, h. 248.

${ }^{23}$ Rachmadi Usman, Aspek-Aspek Hukum Perbankan Di Indonesia, h. 249.

${ }^{24}$ Rachmadi Usman, Aspek-Aspek Hukum Perbankan Di Indonesia, h. 249.

${ }^{25}$ Muhammad, Manajemen Pembiayaan Bank Syariah, h.39.

${ }^{26}$ Muhammad Firdaus, Manajemen Agribisnis, h.4.

${ }^{27}$ Mangasa Augustinus Sipahutar, Persoalan-Persoalan Perbankan Indonesia (Jakarta: Gorga Media, 2007), h. 85.
} 
mendorong peningkatan laju pertumbuhan ekonomi serta menjadi penggerak perkembangan pembangunan daerah. Hal ini dapat membuka peluang perluasan kesempatan kerja bagi masyarakat. Kemajuan ini turut mendukung pertumbuhan sektro-sektor lainnya seperti peningkatan agribisnis dan agroindustri. ${ }^{28}$

Adapun laju pertumbuhan dan penyerapan tenaga kerja sektor industri tahun 2005-2009 digambarkan dalam tabel 2.1 berikut.

Tabel 2.1

Laju Pertumbuhan dan Penyerapan Tenaga Kerja

Sektor Industri 2005-2009

\begin{tabular}{ccc}
\hline Industri & $\begin{array}{c}\text { Pertumbuhan } \\
\text { (\%) }\end{array}$ & $\begin{array}{c}\text { Jumlah Tenaga Kerja } \\
\text { Kumulatif 5 Tahun } \\
\text { (orang) }\end{array}$ \\
\hline Makanan, Minuman dan Tembakau & 4.59 & 514,557 \\
\hline Tekstil, Barang Kulit, dan Alas Kaki & 6.65 & 485,955 \\
\hline Barang Kayu dan Hasil Hutan & 4.91 & 133,119 \\
\hline Kertas dan Barang Cetakan & 7,82 & 42,595 \\
\hline Pupuk, Kimia, dan Barang dari Karet & 10,63 & 143,273 \\
\hline Semen dan Galian non-Logam & 10,13 & 5,918 \\
\hline Logam Dasar, Besi dan Baja & 3,94 & 341,388 \\
\hline Alat Angkut, Mesin dan Peralatan & 12,46 & 96,51 \\
\hline Barang Lainnya & 10,20 & 887,853 \\
\hline TOTAL & 8.56 & $2,651,168$ \\
\hline
\end{tabular}

Sumber: Laporan Pengembangan Sektor Industri 2004-2009 (www.depperin.go.id)

Ketiga, Sektor Jasa; Sektor jasa merupakan sektor yang melayani sektor primer dan sektor sekunder. ${ }^{29}$ Menurut Philip Kotler, jasa dapat didefinisikan sebagai setiap tindakan atau perbuatan yang dapat ditawar-

${ }^{28}$ Pemerintah Kabupaten Bogor, "Industri", artikel diakses pada 16 Maret 2010 dari http:// www.bogorkab.go.id/index.php?option=com_content\&task $=$ view\&id $=63 \&$ Itemid $=286$

${ }^{29}$ Soetrisno P.H, Kapita Selekta Ekonomi Indonesia (Yogyakarta: ANDI OFFSET, 1992), h.161. 
kan oleh suatu pihak kepada pihak lain yang pada dasarnya bersifat intangible (tidak berwujud fisik) dan tidak menghasilkan kepemilikian sesuatu ${ }^{30}$ Sektor jasa terdiri dari banyak subsektor, seperti jasa transportasi, komunikasi, konstruksi, kesehatan, perhotelan, dan keuangan. Sektor jasa pada awalnya merupakan bagian dari sektor produksi, namun setelah semakin berkembang maka sektro jasa bisa dipisahkan menjadi sektor yang berdiri sendiri. ${ }^{31}$

Keempat, Sektor Perdagangan; Sektor ini menurut beberapa ahli disebut-sebut sebagai fondasi untuk memperkuat sektor moneter suatu Negara. Krugman dan Obsfelt menyatakan bahwa proses menuju integrasi keuangan haruslah didahului oleh adanya integrasi di sektor perdagangan. ${ }^{32}$ Dalam struktur ekonomi yang tangguh, perkembangan tiap-tiap sektor bersifat saling mendukung terhadap sektor lainnya. Perkembangan sektor pertanian mendukung perkembangan sektor industri dan sebaliknya, perkembangan sektor perdagangan dapat mendukung perkembangan sektor pertanian dan industri dan sebaliknya, dan seterusnya. ${ }^{33}$

\section{Lain-lain}

Untuk kategori lain-lain, biasanya bank menggolongkannya untuk pembiayaan konsumtif, yaitu pembiayaan yang digunakan untuk memenuhi kebutuhan barang untuk konsumsi. ${ }^{34}$

Berikut adalah data pembiayaan Bank Pembiayaan Rakyat Syaraih berdasarkan sektor ekonomi.

${ }^{30}$ Mohamad Najmudin, "Bisnis Dalam Sektor Jasa Masih Terbuka Lebar", artikel diakses pada 16 Maret 2010 dari http://elearning-ujb.net/artikel/05-2510-6301BISNIS\%20 DALAM\%20SEKTOR\%20JASA.doc

${ }^{31}$ Sjamsul Arifin, dkk, ed., Integrasi Keuangan dan Moneter di Asia Timur (Jakarta: Elex Media Komputindo, 2007), h. 234.

${ }^{32}$ Sjamsul Arifin, dkk, ed., Integrasi Keuangan dan Moneter di Asia Timur, h. 20.

${ }^{33}$ Soetrisno P.H, Kapita Selekta Ekonomi Indonesia, h. 161.

${ }^{34}$ Wawancara pribadi dengan Hasan Basri. Bogor, 2 Februari 2010. 
Tabel 2.2

Pembiayaan Bank Pembiayaan Rakyat Syariah Berdasarkan Sektor Ekonomi

(juta rupiah)

\begin{tabular}{|c|c|c|c|c|c|c|}
\hline $\begin{array}{l}\text { SEKTOR EKONOMII } \\
\text { ECONOMICSECTOR }\end{array}$ & 2005 & 2006 & 2007 & Dec08 & Decos & $\tan -10$ \\
\hline $\begin{array}{l}\text { Pertanian, kehutanan dan sarana pertanian } \\
\text { Agriculture, forestry and ogricultural facilities }\end{array}$ & 11,874 & 17,720 & 24,436 & 41,613 & 54,486 & 56,859 \\
\hline $\begin{array}{l}\text { Pertambangan } \\
\text { Mining } \\
\end{array}$ & 138 & 485 & 944 & 1,287 & 998 & 894 \\
\hline $\begin{array}{l}\text { Perindustrian } \\
\text { Monufocturing }\end{array}$ & 9,207 & 12,465 & 12,447 & 15,885 & 20,420 & 20,643 \\
\hline $\begin{array}{l}\text { Ustrik, gas dan air } \\
\text { Woter, gas and electricity }\end{array}$ & 109 & 748 & 367 & 1,146 & 1,055 & 814 \\
\hline Konstruksi & 3,495 & 6,570 & $\begin{array}{r}16,051 \\
\times \quad \\
\end{array}$ & $\begin{array}{r}26,536 \\
\times \quad \times\end{array}$ & $\begin{array}{r}48,178 \\
\times \quad \times \\
\end{array}$ & $\begin{array}{l}45,235 \\
\times \quad \\
\end{array}$ \\
\hline $\begin{array}{l}\text { Perdagangan, restoran dan hotel } \\
\qquad \text { Trode, restourants and hotels }\end{array}$ & 190,583 & 255,559 & 295,195 & 370,907 & 486,018 & 498,081 \\
\hline $\begin{array}{l}\text { Pengangkutan, pergudangan dan komunikasi } \\
\text { Transport, cargo storage and communication }\end{array}$ & 3,618 & 8,704 & 9,075 & 17,697 & 17,289 & 18,387 \\
\hline Jasa dunia usaha & 49,031 & 72,194 & 99.050 & 140,989 & 176,760 & 174,229 \\
\hline Jasa sosial/masparakat & 5,155 & 5,632 & 6,402 & 22,609 & 16,451 & 15,887 \\
\hline Others & 144,072 & 235,392 & 422,148 & 617,942 & 765,264 & 755,550 \\
\hline Total & 417,282 & 615,469 & 886,117 & $1,256,610$ & $1,586,919$ & $1,586,580$ \\
\hline
\end{tabular}

Sumber: Statistik Perbankan Syariah Januari 2010 (www.bi.go.id)

\section{Profil Dan Deskripsi Responden}

Untuk keperluananalisis dilakukan pengumpulan data dengan memberikan kuesioner kepada pihak yang kompeten dan sesuai dengan arah dan pembahasan skripsi ini yaitu pemegang keputusan pembiayaan bank. Dan dalam hal ini adalah KABID Marketing PT. BPRS Amanah Ummah.

Dalam PT. BPRS Amanah Ummah, KABID Marketing merupakan komite awal pemutus penyaluran pembiayaan setelah Account Officer dan sebelum komite akhir yang dipegang oleh Direksi.

Berikut adalah job description dari KABID Marketing di PT. BPRS Amanah Ummah ${ }^{35}$ :

${ }^{35}$ PT. BPRS Amanah Ummah, Job Description (Bogor: PT. BPRS Amanah Ummah, 2004), h.3-4. 
1. Menyusun taktik dan strategi pemasaran produk perbankan kepada masyarakat dan dunia usaha. Bersama Direksi, Asisten Direksi, Kepala Bidang lainnya menyusun Rencana Kerja dan Anggaran (RKA) tahunan di bidang pemupukan dana dan pembiayaan serta memantau realisasinya.

2. Menangani kegiatan pemasaran lainnya, antara lain permintaan dan atau pemberian informasi antar bank/instansi/pihak ketiga lainnya.

3. Melakukan supervise terhadap kegiatan penghimpunan dana masyarakat yang dilakukan Funding Officer untuk memastikan tercapainya pelayanan yang memuaskan nasabah.

4. Melakukan evaluasi kelayakan terhadap pembiayaan yang diajukan oleh Account Officer untuk memastikan analisa pembiayaan yang diajukan tersebut berkualitas sehingga dapat mengamankan dan meminimalkan resiko pembiayaan bank.

5. Memonitor kelancaran dan ketepatan pengembalian angsuran pembiayaan nasabah untuk memastikan tingkat kolektabilitas dalam posisi sehat.

6. Melakukan pembinaan terhadap kegiatan usaha nasabah yang telah memperoleh pembiayaan untuk menjamin keamanan dan kelancaran pengembalian pembiayaan nasabah kepada bank.

7. Mengevaluasi pembiayaan yang kurang lancer, diragukan dan macet sertamemberikan solusi penyelesaiannya untuk memastikantingkat kolektabilitas nasabah dapat diperbaiki.

8. Melakukan proses remedial seperti penagihan dan eksekusi jaminan bagi nasabah-nasabah tertentu yang tergolong macet untuk menjamin pengembaliankewajiban nasabah kepada bank.

9. Melakukan pembinaan kepada pegawai di bawah supervisinya untuk memastikan pegawai memahami tugas dan tanggung jawabnya serta memiliki tingkat produktivitas yang tinggi.

10. Membuat penilaian kinerja (performance apprasial) stafnya secara berkala.

11. Bertanggung jawab atas segala tugas dan pekerjaanya kepada Direksi.

\section{Evaluasi Penerapan Pembiayaan pada PT. BPRS Amanah Ummah}

Evaluasi penerapan pembiayaan pada PT. BPRS Amanah Ummah, dianalisis dengan menyusun hierarki dalam bentuk struktur. Struktur pada level 
pertama adalah tujuan (goal) sebagai sasaran utama yaitu keputusan pembiayaan. Penyusunan struktur pada level kedua adalah kriteria, kriteria pada penelitian ini adalah faktor-faktor yang mempengaruhi keputusan pembiayaan pada BPRS Amanah Ummahberupa analisis prinsip pembiayaan yaitu return principle, repayment capacity, risk bearing, character, capacity, capital, condition, collateral dan purpose. ${ }^{36}$ Pada level yang terakhir dalam struktur hierarki ini adalah alternatif, alternatif pada penelitian ini adalah sektor ekonomi yang menjadi sasaran pembiayaan BPRS Amanah Ummah, yaitu sektor pertanian, industri, jasa, perdagangan, dan konsumtif. ${ }^{37}$

Kemudian level-level penyusunan struktur tersebut akan dianalisis dengan menggunakan model AHP. Masing-masing elemen dalam level tersebut akan dilakukan pengujian dengan membandingkan prioritas mana yang lebih penting atau tingkat profitabilitasnya lebih utama, beserta perhitungan tingkat konsistensi dari hasil analisis yang telah dilakukan. Berikut adalah gambar struktur hierarki dalam penelitian ini.

Gambar 4.1

Hierarki AHP untuk Keputusan Pembiayaan

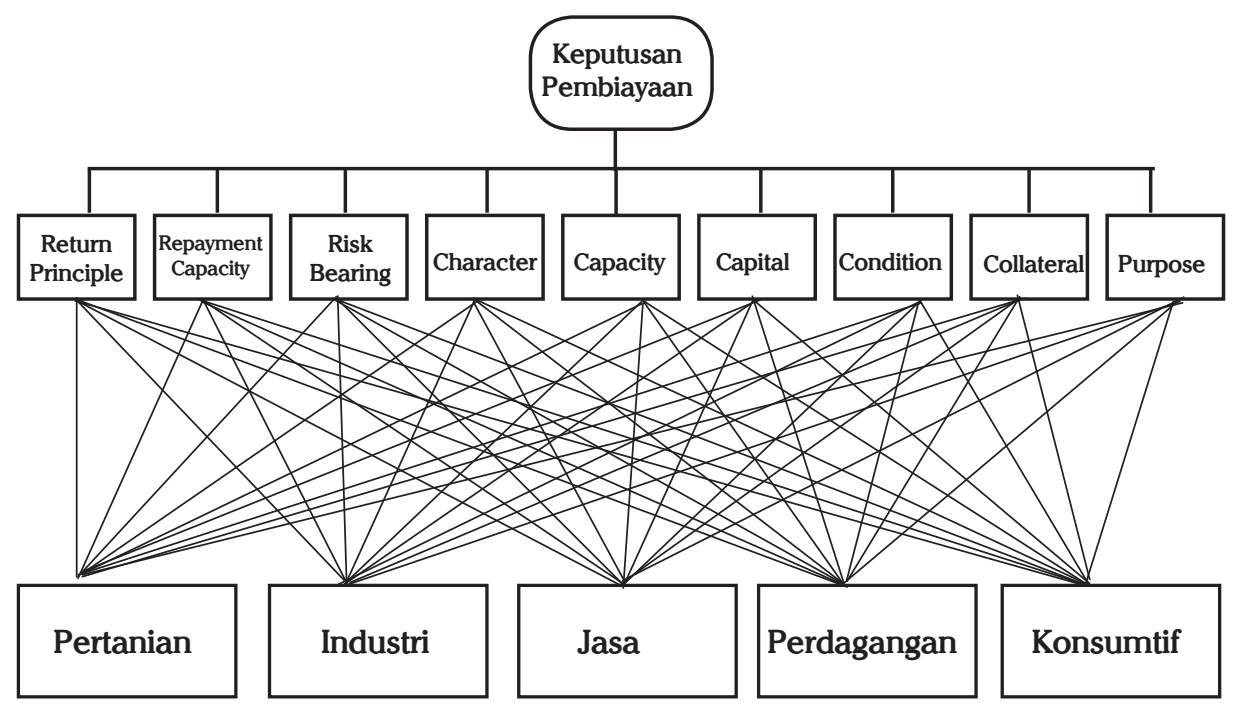

${ }^{36}$ PT. BPRS Amanah Ummah, Pedoman Pembiayaan, h. 2-3.

${ }^{37}$ PT. BPRS Amanah Ummah, Laporan Tahunan 2008, h. 20. 


\section{Analisis Kriteria}

Analisis kriteria ini dilakukan terhadap elemen kriteria berupa faktor-faktor yang mempengaruhi keputusan pembiayaan pada BPRS Amanah Ummah yaitu analisis prinsip pembiayaan.

Kriteria pertama adalah return principle. Return principle yang dimaksud adalah bank harus menilai apakah pembiayaan itu akan menghasilkan tambahan pendapatan sehingga calon nasabah mampu memenuhi kewajibannya untuk membayar pembiayaannya. ${ }^{38}$ Kriteria kedua adalah repayment capacity yaitu kemampuan calon nasabah untuk membayar kembali pembiayaan tepat pada waktunya. ${ }^{39}$ Kriteria ketiga adalah risk bearing yaitu tingkat resiko yang dihadapi usaha yang dibiayai oleh bank. ${ }^{40}$ Kriteria keempat adalah character yaitu kepribadian atau akhlak calon nasabah yang berkaitan dengan niat untuk membayar kembali pembiayaan (willingness to pay). ${ }^{41}$ Kriteria kelima adalah capacity yaitu kemampuan calon nasabah dalam mengelola usahanya. ${ }^{42}$ Kriteria keenam adalah capital jumlah modal sendiri dari calon nasabah yang diharapkan dapat menanggung resiko usaha. ${ }^{43}$ Kriteria ketujuh adalah condition yaitu kondisi perekonomian, terutama masalah pemasaran. ${ }^{44}$ Kriteria kedelapan adalah collateral yaitu bentuk dan jenis jaminan yang disediakan nasabah seandainya nasabah ingkar janji. ${ }^{45}$ Kriteria yang terakhir adalah purpose yaitu tujuan penggunaan pembiayaan. ${ }^{46}$

Hasil analisis berupa nilai pendapat individu terhadap kriteriakriteria tersebut dari kuesioner yang diberikan kepada KABID Marketing menyatakan bahwa penilaian terhadap kepribadian atau akhlak calon

\footnotetext{
${ }^{38}$ PT. BPRS Amanah Ummah, Pedoman Pembiayaan, h.2.

${ }^{39}$ PT. BPRS Amanah Ummah, Pedoman Pembiayaan, h.2.

${ }^{40}$ PT. BPRS Amanah Ummah, Pedoman Pembiayaan, h.2.

${ }^{41}$ PT. BPRS Amanah Ummah, Pedoman Pembiayaan, h.2.

${ }^{42}$ PT. BPRS Amanah Ummah, Pedoman Pembiayaan, h.2.

${ }^{43}$ PT. BPRS Amanah Ummah, Pedoman Pembiayaan, h.2.

${ }^{44}$ PT. BPRS Amanah Ummah, Pedoman Pembiayaan, h.2.

${ }^{45}$ PT. BPRS Amanah Ummah, Pedoman Pembiayaan, h.2.

${ }^{46}$ PT. BPRS Amanah Ummah, Pedoman Pembiayaan, h.2.
} 
nasabah yang berkaitan dengan willingness to pay merupakan kriteria yang paling penting dalam mempengaruhi keputusan pembiayaan pada PT. BPRS Amanah Ummah. Berikut akan diperlihatkan hasil analisis pada tabel 4.1 dibawah ini.

Tabel 4.1

Hasil Analisis Kriteria

\begin{tabular}{|lllllllllllll|}
\hline & RP & RC & RB & CH & CA & CAP & CON & COL & PUR & $\sum$ baris & EV \\
\hline RP & 9.00 & 8.75 & 5.97 & 4.01 & 5.90 & 32.72 & 31.72 & 29.57 & 7.46 & 135.09 & 0.080 \\
\hline RC & 11.36 & 10.19 & 7.28 & 5.68 & 7.46 & 39.15 & 41.32 & 37.95 & 8.94 & 169.34 & 0.100 \\
\hline RB & 20.55 & 19.57 & 10.00 & 6.49 & 12.86 & 58.00 & 55.00 & 54.00 & 13.88 & 250.35 & 0.148 \\
\hline CH & 43.25 & 46.54 & 23.57 & 9.20 & 23.53 & 146.00 & 114.00 & 129.50 & 25.04 & 560.63 & 0.331 \\
\hline CA & 15.70 & 15.63 & 10.17 & 5.59 & 8.99 & 60.00 & 52.00 & 56.80 & 10.67 & 235.54 & 0.139 \\
\hline CAP & 3.68 & 3.52 & 1.70 & 1.24 & 2.42 & 9.00 & 8.91 & 8.48 & 2.56 & 41.51 & 0.024 \\
\hline CON & 4.43 & 4.36 & 2.12 & 1.23 & 2.73 & 11.80 & 9.00 & 9.85 & 2.83 & 48.36 & 0.029 \\
\hline COL & 4.39 & 4.23 & 2.08 & 1.43 & 3.00 & 11.13 & 10.10 & 8.99 & 3.34 & 48.69 & 0.029 \\
\hline PUR & 14.65 & 14.43 & 8.93 & 4.94 & 8.41 & 51.25 & 44.25 & 49.00 & 8.99 & 204.85 & 0.121 \\
\hline Total & & & & & & & & & 1694.34 & 1.000 \\
\hline
\end{tabular}

Hasil analisis kriteria diperoleh bahwa character $(\mathrm{CH})$ memiliki vector prioritas (bobot) yang paling tinggi sebesar 0,331 dengan rasio konsistensi 0,098 yang menyatakan bahwa penilaian akan konsistensi kurang atau sama dengan $0.1(\mathrm{CR} \leq 0.1)$. Kemudian yang diikuti oleh risk bearing (RB) yang memiliki bobot 0,148 . Kemudian capacity (CA) yang memiliki bobot 0,139 . Kriteria purpose (PUR) memiliki bobot 0,121 . Kriteria repayment capacity $(\mathrm{RC})$ memiliki bobot 0,100 . Kriteria return principle (RP) memiliki bobot 0,080 . Faktor collateral (COL) memiliki bobot nilai yang sama yaitu 0,0287. Sedangkan faktor condition (CON) dan capital (CAP) 0,0285 dan 0,024 .

Langkah-langkah perhitungannya seperti yang tertera pada lampiran 3. 


\section{Analisis Alternatif}

Tahapan analisis selanjutnya adalah melakukan penilaian sektor-sektor yang menjadi sasaran keputusan pembiayaan di BPRS Amanah Ummah terhadap kriteria. Ada lima sektor pembiayaan yang menjadi sasaran keputusan pembiayaan dan Sembilan kriteria berupa analisis pembiayaan. Maka aka nada Sembilan analisis.

Analisis yang akan dilakukan adalah membuat peringkat dari masingmasing alternatif terhadap kriteria-kriteria.

\section{1) Return Principle}

Hasil analisis menyatakan bahwa sektor perdagangan merupakan sektor yang dipandang paling mampu menambah pendapatan calon nasabah dan membuatnya mampu memenuhi kewajibannya untuk membayar pembiayaannya yaitu dengan bobot 0,559 dengan rasio konsistensi sebesar 0,06. Dan sektor yang dipandang paling lemah dalam hal menambah pendapatan pengelolanya adalah sektor pertanian yaitu dengan memiliki bobot terendah 0.046 .

Sedangkan pembiayaan konsumtif memang tidak digunakan untuk usaha. Sehingga walaupun memiliki nilai yang sama dengan sektor pertanian, pembiayaan konsumtif berada di bawah sektor pertanian. Seperti yang diperlihatkan pada gambar 4.2 berikut ini.

Gambar 4.2

Prioritas Level Alternatif pada Return Principle

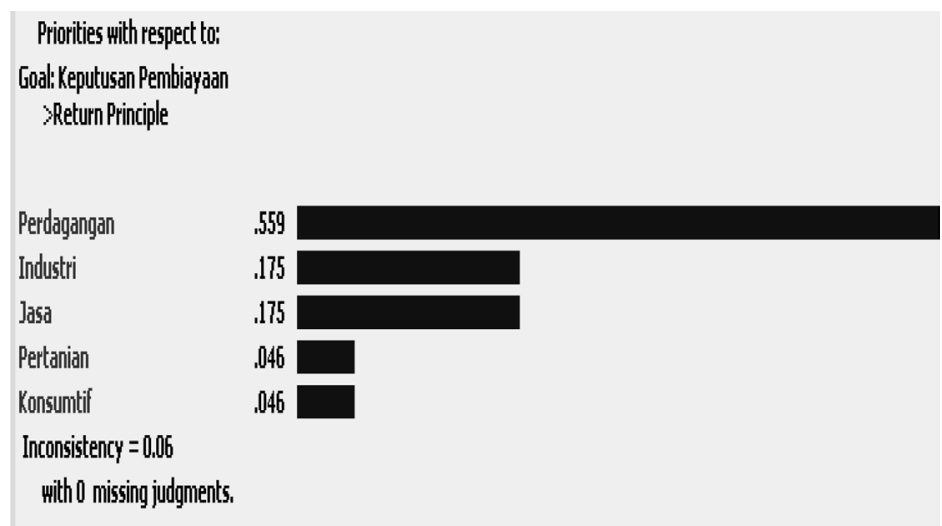


2) Repayment Capacity

Hasil analisis menyatakan bahwa calon nasabah sektor perdagangan dipandang paling memiliki kemampuan utnuk membayar kembali pembiayaan tepat waktu yaitu dengan nilai 0,582 dengan rasio konsistensi 0,05. Dan calon nasabah dari sektor pertanian dan industri masih dipandang masih belum mampu membayar pembiayaan tepat waktu yaitu dengan nilai $\mathbf{0 , 0 5 9}$. Seperti yang diperlihatkan pada gambar 4.3 berikut ini.

Gambar 4.3

Prioritas Level Alternatif pada Repayment Capacity

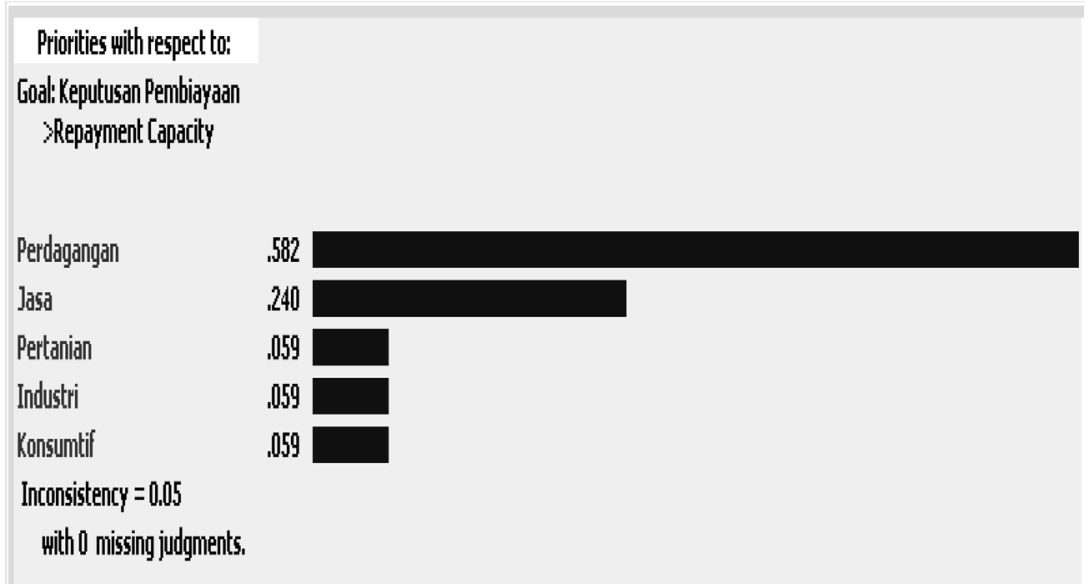

3) Risk Bearing

Hasil analisis menyatakan bahwa untuk tingkat resiko yang dihadapi, sektor jasa dan perdagangan dipandang memiliki tingkat resiko yang rendah yaitu dengan memiliki bobot nilai tertinggi masingmasing 0,343 dengan rasio konsistensi sebesar 0,01. Dan yang paling dipandang masih beresiko tinggi sehingga dapat menimbulkan lambatnya pengembalian atau bahkan tidak kembali adalah sektor pertanian dengan bobot nilai terendah bahkan dibawah bobot nilai pembiayaan konsumtif yaitu 0,055 . Seperti yang diperlihatkan pada gambar 4.4 berikut ini. 
Gambar 4.4

Prioritas Level Alternatif pada Risk Bearing

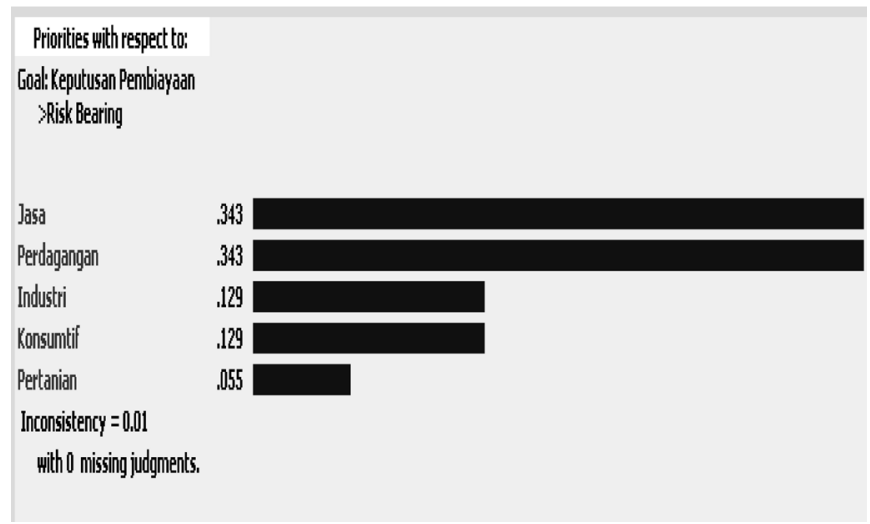

4) Character

Hasil analisis menyatakan bahwa dalam hal kepribadian calon nasabah yang berkaitan dengan willingness to pay semua calon nasabah dari berbagai sektro dipandang sudah menunjukkan i'tikad yang baik untuk membayar pembiayaan yang diberikan oleh bank. Hal ini ditunjukkan dengan bobot nilai sektor pertanian, sektor industri, sektor jasa, dan sektor perdagangan yaitu masing-masing 0,238 dengan rasio konsistensi $\mathbf{0 , 0 0}$. Sedangkan untuk pembiayaan konsumtif memiliki bobot nilai 0.048 . Seperti yang diperlihatkan pada gambar 4.5 berikut.

Gambar 4.5

Prioritas Level Alternatif pada Character

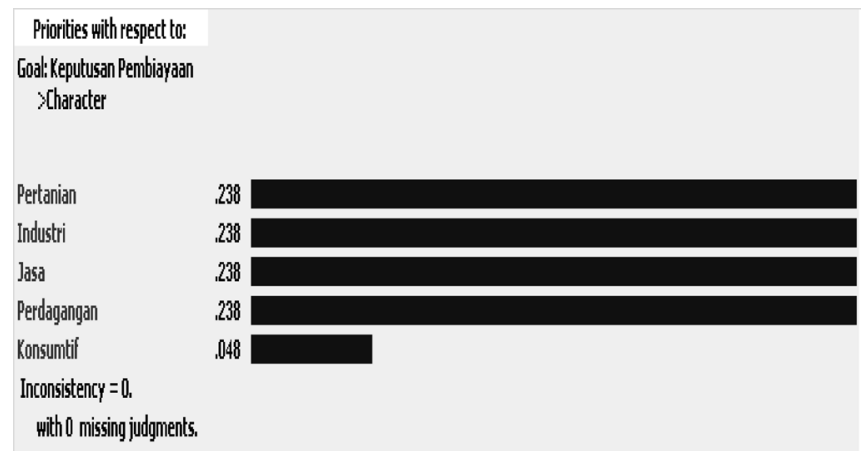




\section{5) Capacity}

Hasil analisis menyatakan bahwa dalam penilaian kemampuan nasabah mengelola usahanya, calon nasabah dari sektor industri, sektro jasa, dan sektor perdagangan dipandang paling memiliki kemampuan tersebut sehingga dapat meminimalisir terhambatnya pengembalian pembiayaan yang diberikan oleh bank yaitu dengan bobot nilai sebesar 0.294 dengan rasio konsistensi sebesar 0,00. Sedangkan untuk sektor pertanian masih dipandang belum dapat dikelola dengan baik hal tersebut ditunjukkan dengan nilai terkecil yaitu 0,059 . Seperti yang diperlihatkan pada gambar 4.6 berikut.

Gambar 4.6

Prioritas Level Alternatif pada Capacity

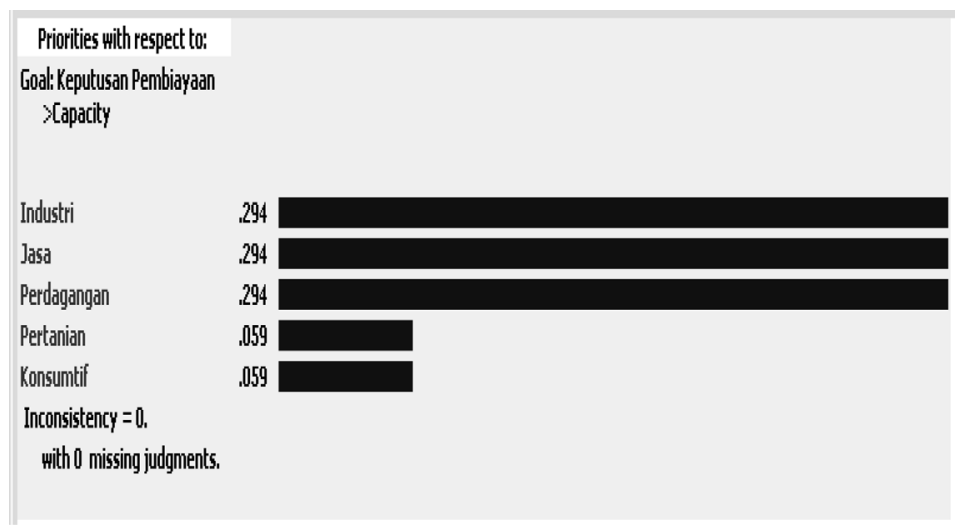

6) Capital

Hasil analisis menyatakan bahwa dalam penilaian terhadap jumlah modal yang dimiliki calon nasabah sebagai penanggung resiko usaha adalah baik bagi semua sektor pembiayaan yaitu dengan nilai 0,2 dan rasio konsistensi sebesar $\mathbf{0 , 0 0}$. Hal ini disebabkan oleh persyaratanyang diberikan bank atas pengajuan pembiayaan terhadap setiap usaha harus sudah berjalan minimal 1 tahun. Hasil analisis diperlihatkan pada gambar 4.7 berikut. 


\section{Gambar 4.7}

Prioritas Level Alternatif pada Capital

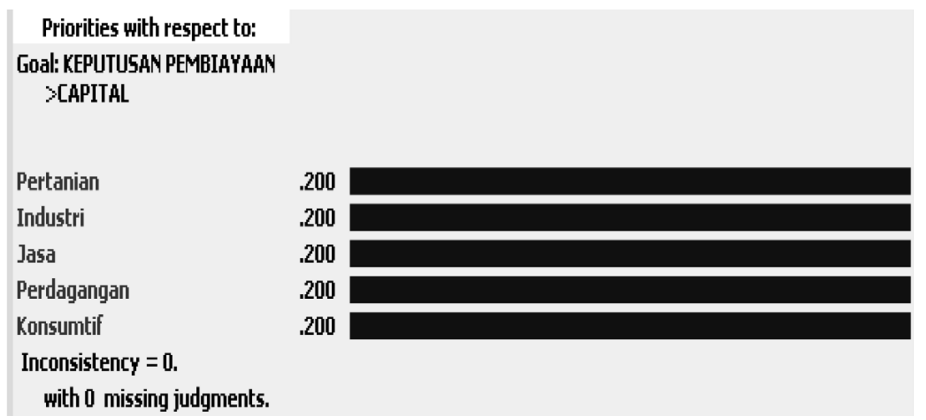

\section{7) Condition}

Hasil analisis terhadap keadaan ekonomi secara luas, pemasaran, sampai kepada iklim yang akan mempengaruhi sektor usaha nasabah dalam pencapaian kemampuan pengembalian pembiayaan, sektor pertanian masih dipandang masih sangat beresiko, hal ini ditunjukkan dengan bobot nilai sektor ini yang kecil yaitu 0,059. Sedangkan untuk sektor industri, jasa dan perdagangan dipandang tidak memiliki kendala yang dapat menyebabkan terhambatnya pengembalian pembiayaan dari segi condition dengan memiliki bobot nilai tertinggi yaitu 0.294. Dengan rasio konsistensi 0,00. Hasil analisis diperlihatkan pada gambar 4.8 berikut.

Gambar 4.8

Prioritas Level Alternatif pada Condition

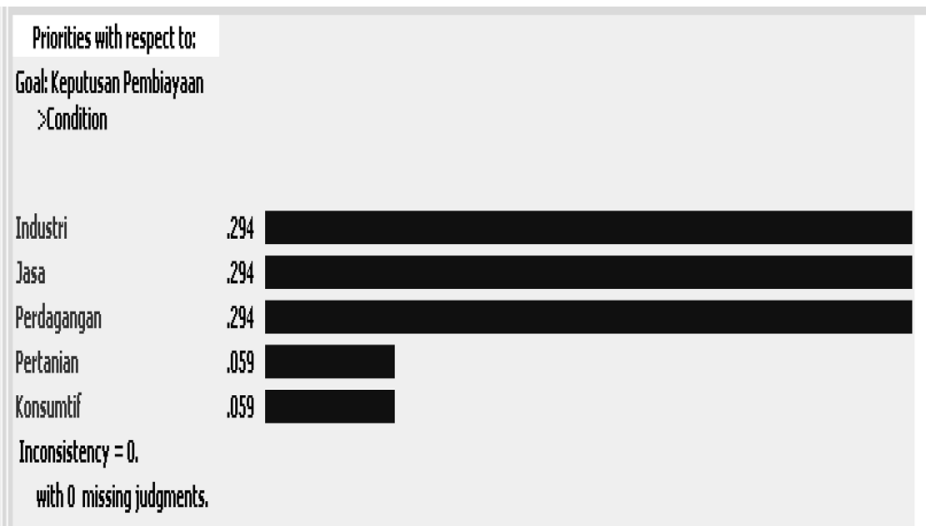


8) Collateral

Hasil analisis terhadap bentuk dan jenis jaminan yang disediakan nasabah, sektor industri dan perdagangan yang dipandang paling memungkinkan untuk memenuhinya, yaitu dengan bobot nilai 0.385 dengan konsistensi rasio 0,00. Sedangkan sektor pertanian, jasa dan pembiayaan konsumtif masih belum bisa memenuhi jaminan yang bank minta dengan bobot nilai $\mathbf{0 , 0 7 7}$. Seperti yang diperlihatkan pada gambar 4.9 berikut.

9) Purpose

Hasil analisis terhadap tujuan penggunaan pembiayaan, baik sektor pertanian, industri, jasa, perdagangan dan pembiayaan konsumtif dipandang bank memiliki tujuan penggunaan pembiayaan yang baik. Hal ini ditunjukkan dengan bobot kelima sektor pembiayaan memiliki nilai yang sama yaitu 0,2 dengan rasio konsistensi 0,00 . Seperti diperlihatkan pada gambar 4.10 berikut.

Gambar 4.10

Prioritas Level Alternatif pada Purpose

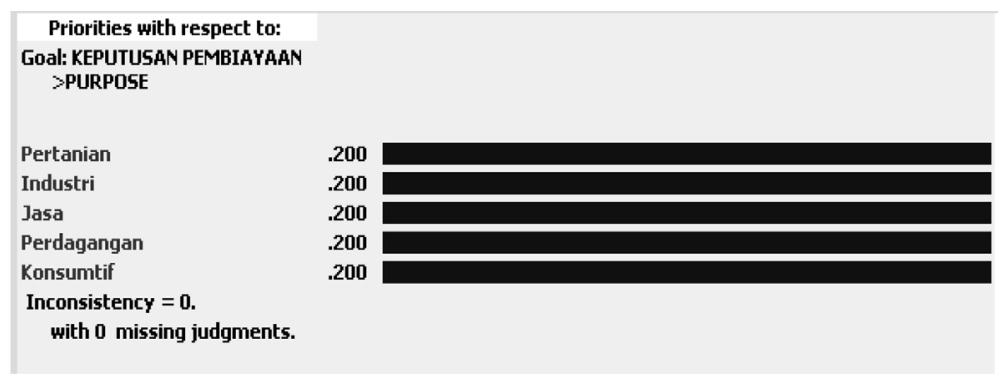

\section{Analisis Peringkat Alternatif}

Tahapan analisis akhir dalam penelitian ini adalah melakukan penilaian terhadap level alternatif. Berdasarkan analisis penilaian alternatif sektor pembiayaan terhadap kriteria berupa analisis pembiayaan pada PT. BPRS Amanah Ummah, dapat ditentukan alternatif prioritas atau sektor apa yang mendapat nilai prioritas tertinggi sebagai gambaran kelayakan sektor tersebut menerima pembiayaan dari bank. 
Hasil analisis menyatakan bahwa sektor perdagangan merupakan alternatif yang mendapat prioritas paling tinggi dengan bobot sebesar 0,287 dengan rasio konsistensi sebesar 0.05. Hal ini dapat disebabkan oleh keadaan sektor perdagangan terhadap level kriteria, dimana sektor perdagangan dipandang memenuhi hampir setiap kriteria. Selain itu, keadaan yang bankable dari sektor perdagangan disebabkan oleh lokasi PT. BPRS Amanah Ummah yang berada di pasar leuwiliang Bogor.

Sedangkan level alternatif yang menjadi prioritas kedua adalah sektor jasa dengan bobot sebesar $\mathbf{0 , 2 4 5}$. Sektor memang masih memiliki potensi yang besar yang belum tergali. Dari jasa pada bidang pariwisata dapat berupa resto atau penginapan pada dasarnya bisa menjadi sasaran pembiayaan bagi bank di Kota Bogor. Karena sampai saat ini, Bogor masih menjadi pilihan warga luar kota untuk menghabiskan liburan.

Kemudian level alternatif yang menjadi prioritas ketiga adalah sektor industri yang memiiliki bobot sebesar $\mathbf{0 , 2 1 8}$. Hasil analisis level alternatif ini menunjukkan sisi kelemahan sektor ini adalah pada kriteria repayment capacity dengan menempati prioritas keempat dengan bobot nilai 0.059, kemudian pada kriteria risk bearing dengan menempati prioritas ketiga dengan bobot nilai 0.129 .

Level alternatif yang menjadi prioritas keempat adalah sektor pertanian yang memiliki bobot sebesar $\mathbf{0 , 1 5 7}$. Hasil analisis level alternatif ini menunjukkan sisi kelemahannya pada faktor return principle dengan menempati prioritas keempat dengan bobot nilai 0,046. Dan untuk kriteria risk bearing sektor ini memiliki bobot nilai terendah bahkan dibawah pembiayaan konsumtif, hal tersebut menunjukkan bahwa resiko yang dihadapi sektor ini dipandang sangat tinggiyaitu dengan bobot nilai 0.055. Untuk faktor capacity sektor ini memiliki bobot 0,059 menempati prioritas keempat.

Sedangkan pada level alternatif yang menjadi prioritas terakhir adalah pembiayaan konsumtif yang hanya memiliki bobot terendah yaitu 0,093. Penilaian terhadap alternatif ini yang rendah dinilai wajar, karena pembiayaan konsumtif memang tidak menggunakan dana pembiayaan untuk modal kerja ataupun investasi. Namun, bobot nilai alternatif ini terhadap risk bearing memiliki nilai lebih tinggi dibanding dengan sektor 
pertanian. Dengan kata lain, pembiayaan konsumtif lebih memiliki tingkat resiko yang cukup kecil jika dibandingkan sektor pertanian. Hasil dari analisis diatas ditampilkan pada gambar 4.11 berikut.

Gambar 4.11

Prioritas Level Alternatif pada Keputusan Pembiayaan

Synthesis with respect to: Goal: Keputusan Pentiaysan

Overall Inconistency $=$, 105

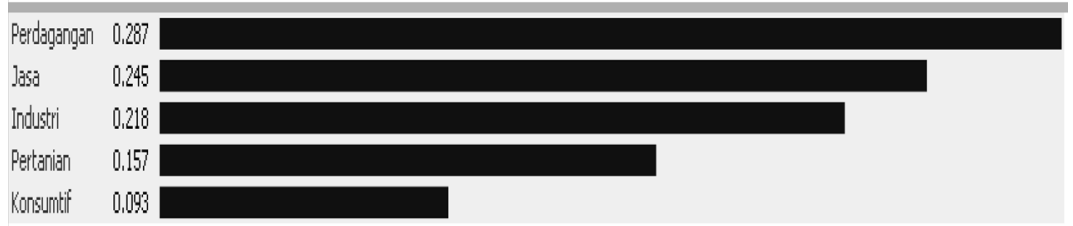

Dari analisis-analisis yang telah dijelaskan dapat diketahui bahwa untuk mencapai efektivitas pembiayaan dengan melihat ketepatan keputusan pembiayaan pada PT. BPRS Amanah Ummah adalah dengan menurut pada vektor prioritas terbesar pada masing-masing level tersebut. Berdasarkan analisis yang telah dilakukan, pada level faktor dan level alternatif pada keputusan pembiayaan yang memiliki bobot terbesar adalah penilaian terhadap kepribadian atau akhlak calon nasabah berkaitan dengan willingness to pay atau character, dan sektor perdagangan.

\section{Penutup}

Dari hasil analisis data yang telah dilakukan pada BAB IV, maka dapat diambil kesimpulan sebagai berikut:

Pengalokasian pembiayaan pada BPRS Amanah Ummah belum sesuai (mismatch) dengan vektor prioritas terbesar berdasarkan analisis penilaian alternatif terhadap faktor yang mempengaruhi keputusan pembiayaan. Pada realisasi pembiayaan di PT. BPRS Amanah Ummah, porsi terbesar adalah sektor perdagangan (55,92\%), disusul pembiayaan konsumtif (30,18\%), jasa (9,55\%), pertanian (2,39\%), terakhir sektor industri (1,96\%). Sedangkan berdasarkan analisis yang telah dilakukan, 
sektor perdagangan memiliki priritas tertinggi $(0,287)$, disusul sektor jasa $(0,245)$, sektor industri $(0,218)$, sektor pertanian $(0,157)$, terakhir pembiayaan konsumtif $(0,093)$.

Kelemahan sektor-sektor pembiayaan berdasarkan prinsip analisis pembiayaan adalah sebagai berikut:

1) Sektor pertanian masih dipandang lemah dalam tiga faktor. Pertama adalah return principle, bank masih memandang sektor ini belum mampu menambah penghasilan para petani yang akan berdampak kepada ketidakmampuan mereka untuk membayar pembiayaan dari bank. Kedua adalah faktor repayment capacity, bank memandang calon nasabah dari sektor ini belum mampu membayar kembali pembiayaan tepat waktu. Ketiga adalah risk bearing, bank masih memandang tingkat resiko pada sektor ini masih sangat tinggi. Keempat adalah faktor capacity, bank masih belum yakin akan kemampuan para petani dalam mengelola sektor pertanian. Kelima adalah condition, bank masih memandang sektor pertanian tidak didukung oleh kondisi perekonomian, alam serta pemasarannya dalam mencapai tingkat profitabilitas yang maksimal.

2) Sektor industri masih dipandang lemah dalam repayment capacity.

3) Sektor jasa hanya dipandang lemah dalam faktor collateral. Bank masih memandang sektor ini sulit untuk memenuhi bentuk dan jenis jaminan yang sewaktu-waktu dapat diminta oleh bank sebagai antisipasi jika nasabah ingkar janji.

4) Sedangkan pembiayaan konsumtif dari sembilan faktor analisis pembiayaan memiliki nilai prioritas terendah terhadap enam faktor. Yaitu faktor return principle, repayment capacity, character, capacity, condition, dan collateral. Penilaian tersebut dipandang wajar karena pembiayaan konsumtif tidak digunakan untuk modal usaha atau investasi. Namun, keadaan yang demikian menjadikan pembiayaan konsumtif tidak memberikan tingkat profitabilitas yang tinggi bagi bank. 


\section{Pustaka Acuan}

"Metode Analytical Hierarchy Process (AHP)", artikel diakses pada 21 Agustus 2009 dari http://www.ittelcom.ac.id/library/index.php?vie $\mathrm{w}=$ article \& catid $=25 \% 3$ Aindutri \&id $=252 \% 3$ Aahp\&option $=$ com content\&Itemid $=15$

Anshori, Abdul Ghofur. Perbankan Syariah di Indonesia. Yogyakarta: Gadjah Mada University Press, 2007.

Antonio, Muhammad Syafi'i. Bank Syariah Dari Teori ke Praktik. Jakarta: GEMA INSANI, 2001.

Arifin, Sjamsul. dkk. Ed.. Integrasi Keuangan dan Moneter di Asia Timur. Jakarta: Elex Media Komputindo, 2007.

Arifin, Zainul. Dasar-Dasar Manajemen Bank Syariah, cet.IV. Jakarta: Pustaka Alvabet, 2006.

Bahreisj, Husein. Himpunan Fatwa. Surabaya: Al-Ikhlas, 1992.

Bank Indonesia, "Sekilas Perbankan Syariah Di Indonesia", artikel diakses pada 11 Desember 2009 dari http://www.bi.go.id/web/id/Perbankan/ Perbankan+Syariah/

Diyah. "Manajemen Penyaluran Dana". Artikel diakses pada 25 Januari 2010 dari http://microfin-center.com/web/index.php?option=com content $\&$ view $=$ article $\& i d=50:$ manajemen-penyalurandana\&catid $=34$ :artikel-ekonomi-syariah\&itemid $=56$

Farida, Rora. "Analisis Penilaian Dan Faktor-Faktor Penyaluran Pembiayaan Syariah Dalam Pembiayaan Agribisnis Pada KBMT Khidmatul Ummah." Skripsi S1 Fakultas Pertanian, Institut Pertanian Bogor, 2007.

Fewidarto, Pramono D. "Aplikasi Metoda AHP (Analitic Hierarchy Process) untuk Perencanaan Stratejik". Artikel diakses pada 16 Maret 2010 dari http://openstorage.gunadarma.ac.id/pub/dokumen-borang-institusi/ Evauasi-diri/1\%20Presentasi/TPK\%20Pimpi\%20PT.ppt

Firdaus, Muhammad. Manajemen Agribisnis, Jakarta: PT Bumi Aksara, 2008. 
Gunawan, Dhani, "Perbankan Syariah Menuju Millenium Baru: Suatu Tinjauan Pengembangan, Pengawasan dan Prospek", artikel diakses pada tanggal 7 Desember 2009 dari http://www.bi.go.id/NR/rdonlyres/E736319E-6D524199-ACF9-247D719BF119/3018/bempvol2no3des99.pdf

Hasan, Aslam. "Pendekatan-Pendekatan Dalam Analisis Kredit". Artikel diakses pada 5 Januari 2010 dari http://belajarkredit.blogspot. com/2009/11/pendekatan-pendekatan-dalam-analisis.html

Jusuf, Jopie. Analisis Kredit Untuk Account Officer, cet.VIII. Jakarta: PT. Gramedia Pustaka Utama, 2007.

Kusrini. Konsep Dan Aplikasi Sistem Pendukung Keputusan. Yogyakarta: ANDI, 2007.

Lubis, Abdul Fatah. "Analisa Pertumbuhan Bisnis Bank Syariah." Skripsi S1 Fakultas Syariah Dan Hukum Universitas Islam Negeri Syarif Hidayatullah Jakarta, 2008.

Metode Analytical Hierarchy Process (AHP). Artikel diakses pada 13 Januari 2010 dari http://www.ittelkom.ac.id/library/index.php?view=articl e\&catid $=25 \% 3$ Aindustri\&id $=613 \% 3$ Ametode-analytical-hierarchyprocess-ahp\&option $=$ com_content $\&$ Itemid $=15$

Muhammad. Manajemen Pembiayaan Bank Syariah, Yogyakarta: UPP AMK YPKN, 2005.

Mulyani, Sri. "Analisis Perilaku Konsumen Terhadap Produk Tabungan Perbankan Syariah (Studi Kasus Pada BRI Syariah Cabang Solo)." Skripsi S1 Jurusan Ekonomi Islam, Sekolah Tinggi Agama Islam Surakarta, 2007.

Pemerintah Kabupaten Bogor, "Industri". Artikel diakses pada 16 Maret 2010 dari http://www.bogorkab.go.id/index.php?option=com_conten t\&task $=$ view\&id $=63 \&$ Itemid $=286$

PT. BPRS Amanah Ummah. Laporan Tahunan 2008. Bogor: PT. BPRS Amanah Ummah, 2008.

, Pedoman Pembiayaan (Bogor: PT. BPRS Amanah Ummah, 2003), h.10-12. 
, "Keputusan Direksi PT. BPRS Amanah Ummah tentang Pembentukan Team Komite Pembiayaan PT. BPRS Amanah Ummah". Maret, 2003.

, Job Description. Bogor: PT. BPRS Amanah Ummah, 2004.

, "Keputusan Direksi PT. BPRS Amanah Ummah tentang Pembentukan Team Komite Pembiayaan PT. BPRS Amanah Ummah", (Maret, 2003).

Rasjid, Sulaiman. Fiqh Islam. Jakarta: Kurnia Esa, 1984.

Reddy, A. Rama Mohan. dkk. An Integrated approach of Analytical Hierarchy Process Model and Goal Model (AHP-GP Model) for Selection of Software Architecture. IJCSNS International Journal of Computer Science and Network Security. VOL.7. no.10. October 2007.

Rochaety, Ety. dkk. Metodologi Penelitian Bisnis Dengan Aplikasi SPSS. Jakarta: Penerbit Mitra Wacana Media, 2007.

Seputro, Heri. "Proses Hirarki Analitik". Artikel diakses pada 29 November 2009 dari http://www.scribd.com/doc/2908406/Modul-6-AnalyticHierarchy-Process

Sipahutar, Mangasa Augustinus. Persoalan-Persoalan Perbankan Indonesia. Jakarta: Gorga Media, 2007.

Soetrisno P.H, Kapita Selekta Ekonomi Indonesia. Yogyakarta: ANDI OFFSET, 1992.

Sula, Muhammad Syakir. Asuransi Syariah (Life and General): Konsep dan Sistem Operasional, cet.I. Jakarta: Gema Insani Press, 2004.

Suyatno, Thomas. dkk, Dasar-Dasar Perkreditan. Jakarta: Gramedia Pustaka Utama, 1995.

Syafar, Muhammad. "Analisis Efektivitas Pembiayaan Sistem Syariah Terhadap Petani Agribisnis Sayuran Pada Program UPK Ikhtiar." Skripsi S1 Fakultas Ekonomi dan Manajemen, Institut Pertanian Bogor, 2006.

Undang-Undang Republik Indonesia: Tentang Perbankan Syariah. Nomor 21 Tahun 2008. 
Undang-Undang Republik Indonesia Nomor 10 Tahun 1998 Tentang Perubahan Atas Undang-Undang Republik Indonesia Nomor 7 Tahun 1992 Tentang Perbankan.

Usman, Rachmadi. Aspek-Aspek Hukum Perbankan Di Indonesia. Jakarta: PT. Gramedia Pustaka Utama, 2001. 